\title{
Play Teach Play: Pengaruhnya Terhadap Kemampuan Passing Futsal
}

\section{Play Teach Play: The Effect on Futsal Passing Skills}

\author{
Boby Agustan ${ }^{1}$, Ahmad Roni Hidayat ${ }^{2}$ \\ 1,2 Prodi PJKR STKIP Muhammadiyah Kuningan, Indonesia \\ email: bobyagustan@upmk.ac.id11, ahmadronii378@gmail.com² \\ doi : https://doi.org/10.20884/1.paju.2021.2.2.3875
}

\begin{abstract}
Abstrak
Model Play Teach Play menjadi salah satu model pembelajaran yang perlu dikembangkan pada pembelajaran permainan futsal di sekolah. Tujuan dari penelitian ini yaitu untuk mengetahui peningkatan kemampuan passing dalam permainan futsal melalui model pembelajaran play teach play. Metode penelitian yang digunakan adalah eksperimental, dengan desain penelitian yaitu preeksperimental one group pretest-posttest design. Sampel siswa sebanyak 18 orang dengan menggunakan teknik purposive sampling. Teknik pengumpulan data dilakukan dengan pre-test, treatment dan posttest. Instrumen penelitian menggunakan tes passing futsal yang sudah terstandar. Teknik analisis data menggunakan SPSS dengan melalui uji normalitas, uji homogenitas, dan uji hipotesis. Hasil menunjukkan bahwa terdapat pengaruh model pembelajaran play teach play terhadap kemampuan passing siswa dalam permainan futsal. Model pembelajaran play teach play efektif untuk diterapkan dalam pembelajaran penjas dengan materi olahraga permainan, khusunya futsal. Penelitian selanjutnya dapat menerapkan model pembelajaran lain dan bahkan membandingkan antar dua model berbeda untuk mengetahui peningkatkan keterampilan teknik dasar dalam permainan futsal.
\end{abstract}

Kata Kunci : Model Pembelajaran, Play Teach Play, Passing, Futsal

\begin{abstract}
Play Teach Play model is one of the learning models that need to be developed in learning futsal in schools. The purpose of this study was to determine the increase in passing skills in futsal games through the play teach play learning model. The research method used was experimental, the research design was pre-experimental one group pretest-posttest design. The sample of students was 18 people using purposive sampling technique. Data collection techniques were carried out by pre-test, treatment and posttest. The research instrument used standardized futsal passing tests. The data analysis technique used SPSS through normality test, homogeneity test, and hypothesis testing. The results show that there is an effect of the play teach play learning model on students' passing abilities in futsal games. The learning model of play teach play is effective to be applied in physical education learning with game sports materials, especially futsal. Further research can apply other learning models and even
\end{abstract}

Alamat Koresponden : Prodi PJKR STKIP Muhammadiyah Kuningan, Indonesia Email : bobyagustan@upmk.ac.id 
compare between two different models to find out how to improve basic technical skills in futsal games.

Keywords : Learning Model, Play Teach Play, Passing, Futsal

\section{PENDAHULUAN}

Futsal merupakan olahraga baru di Indonesia dan sedang berkembang dengan cepat. Hal ini dibuktikan dengan banyaknya kompetisi seperti antar pelajar dari tingkat Sekolah Dasar hingga Sekolah Menengah Atas, dan juga antar mahasiswa sampai kelompok usia/umum. Kejuaraan dan berbagai pertandingan futsal antar pelajar banyak diselengarakan diberbagai daerah di Indonesia dengan tujuan untuk mengembangkan dan mencari atlet potensial (Aswadi, et al., 2015; Kharisma \& Mubarok, 2020).

Perkembangan olahraga futsal dikalangan pelajar dapat berjalan dengan cepat karena didukung dengan diajarkannya olahraga futsal diberbagai sekolah, sehingga siswa dapat dengan cepat mengenal dan menggemari olahraga ini. Permainan futsal menjadi salah satu materi yang diajarkan kepada siswa diberbagai sekolah, khusunya untuk mengatasi keterbatasan fasilitas untuk melaukan pembelajaran sepakbola (Adi, et al., 2019; Iksan \& Rachmat, 2013).

Pembelajaran futsal di sekolah diterapkan oleh guru untuk dapat mengembangkan potensi siswa baik dari segi kognitif, afektif dan psikomotor. Hasil penelitian menunjukan bahwa potensi siswa dapat dikembangkan melalui berbagai aktivitas olahraga dan permainan (Budi, et al., 2019; Hadiana, et al., 2020). Untuk dapat mengembangkan potensi siswa, permainan futsal yang diajarkan harus dimulai dari teknik dasar permainan yang mudah dikuasai siswa. Teknik dasar futsal yang diajarkan kepada siswa yaitu passing, stoping, dribbling dan shooting (Hadiana, et al., 2020; Narlan, et al., 2017).

Teknik dasar yang fundamental dan perlu untuk dikuasai oleh siswa dalam permainan futsal yaitu passing. Passing yaitu mengoper atau menedang bola kepada teman satu tim untuk menjalankan permainan (Eka \& Darmawan, 2014; Novriza, 2015). Teknik dasar passing meupakan tahap awal bagi siswa untuk belajar permainan futsal. Hasil penelitian menunjukan bahwa kemampuan passing yang baik dapat menunjang permainan futsal dengan lebih baik dan mempermudah dalam menciptakan goal ke gawang lawan (Fahrizqi, 2018; Jaenudin, et al., 2018). Berdasarkan hasil penelitian tersebut maka, teknik dasar passing menjadi fokus yang penting dalam permainan futsal. 
Boby Agustan \& Ahmad Romi Hidayat | Play Teach Play: Pengaruhnya Terhadap Kemampuan Passing Futsal

Penguasaan teknik dasar permainan futsal, khususnya passing dapat dilakukan dengan guru menerapkan model pembelajaran selama proses belajar mengajar di lapangan. Pemilihan model pembelajaran yang tepat dapat mempermudah guru dalam menyampaikan materi sehinga siswa mudah untuk memahami tujuan pembelajaran (Karisman, 2020; Nur et al., 2020; Sampurno \& Qohhar, 2020). Berdasarkan hal tersebut maka penting bagi guru memiliki pemahaman dan keterampilan dalam mengaplikasikan berbagai model pembelajaran.

Kenyataan yang terjadi dilapangan, guru masih banyak yang menggunakan satu model pembelajaran dan diterapkan disetiap materi ajar. Minimnya variasi model pembelajaran yang digunakan guru membuat siswa menjadi jenuh dengan materi yang diajarkan. Teknik pemberian model pembelajaran terhadap siswa dalam proses pembelajaran merupakan suatu keterampilan dari seorang guru dalam mengajarkan materi kepada siswa (Budi \& Listiandi, 2021; Friskawati, Ilmawati, \& Suherman, 2017; Gustiawati, 2016). Pemilihan suatu model pembelajaran harus disesuaikan dengan materi yang akan diajarkan,karena tingkatan afektif, dan psikomotor setiap siswa berbeda-beda.

Berdasarkan hasil observasi yang dilakukan di SMP Binaul Ummah memperlihatkan beberapa permasalahan diantaranya, (1) siswa terlihat kurang bersemangat dalam mengikuti pembelajaran penjas, (2) siswa tidak terlibat aktif dalam proses pembelaajran dan tanya jawab sehingga kegiatan belajar mengajar hanya terpusat pada guru saja, (3) proses pembelajaran kurang mendukung dalam menciptakan rasa keingintahuan siswa terhadap materi yang diajarkan guru, (4) penguasaan Teknik passing siswa masih cukup rendah, sehingga permainan futsal tidak berjalan baik dan (5) sebagian besar siswa melakukan teknik passing yang tidak tepat sasaran..

Berdasarkan permasalahan tersebut, maka perlu adanya sebuah model pembelajaran yang baru dan dapat menarik minat siswa untuk belajar. Model pembelaajran yang dapat diterapkan yaitu jenis play teach play. Model pembelajaran play teach play merupakan salah satu model dipembelajaran pendidikan jasmani yang menekankan kepada aktivitas bermain selama pembelajaran, sehingga seluruh siswa dapat terlibat aktif dalam proses belajar. Model pembelajaran play teach play memiliki ciri khas berpusat kepada siswa dan materi yang diajarkan dilakukan dengan pendekatan permainan (Permana \& Istiadah, 2018; Suherman, 2009; Ulfah, 2019). 
Proses pembelajaran dengan model play teach play diawali dengan guru memberikan materi yang akan diajarkan, dalam hal ini mengenai teknik dasar passing dalam permainan futsal. Setelah itu murid mempraktikkan bagaimana cara melakukan passing dalam bentuk permainan/game. Ketika selesai melakukan game guru kemudian memberikan arahan dan perbaikan kepada siswa, selanjutnya siswa kembali melakukan permainan/game. Karakteristik model pembelajaran play teach play memungkinkan siswa untuk meperoleh pengalaman dan penguasaan keterampilan gerak dengan lebih banyak, sehingga suasana pembelajaran lebih menyenangkan.

Berdasarkan paparan tersebut maka perlu dikaji secara empiris mengenai pengaruh model pembelajaran play teach play untuk meningkatkan teknik dasar passing dalam permainan futsal, khususnya pada siswa SMP.

\section{METODE}

Penelitian ini menggunakan metode eksperimen dengan desain penelitian mengunakan pre-experimental jenis one-group pretest-posttest design. Desiain penelitian tertera pada gambar 1. dibawah ini (Sugiyono, 2016).

\section{$O_{1} \times O_{2}$}

Gambar 1. One-Group Pretest-Posttest Design

Sampel yang digunakan dalam penelitian ini yaitu sebanyak 18 siswa laki-laki kelas VIII SMP Binaul Ummah angkatan 2020. Instrumen penelitian menggunakan tes Passing Futsal yang sudah valid berdasarkan (Nurhasan dan Chalil, 2007). Analisis data menggunakan aplikasi SPSS versi 21 dengan melakukan Langkah-langah yaitu mentukan Normalitas, Homogenitas dan Uji t.

\section{HASIL}

\section{Uji Normalitas}

Uji normalitas dilakukan untuk menguji apakah semua variabel berdistribusi normal atau tidak. Uji normalitas pada penelitian ini menggunakan metode KolmogorovSmirnov, dalam perhitungan menggunakan program SPSS 21. Untuk mengetahui normal tidaknya adalah jika sig.> 0.05 maka normal dan jika sig.< 0.05 dapat dinyatakan data 
Boby Agustan \& Ahmad Romi Hidayat | Play Teach Play: Pengaruhnya Terhadap Kemampuan Passing Futsal

tidak normal. Hasil perhitungan yang diperoleh dapat dilihat pada Tabel 1. dibawah ini.

Tabel 1. Uji Normalitas Hasil Nilai Pre Test dan Post Test

\begin{tabular}{ccc}
\hline Hasil Tes & Nilai Sig (2-Tailed) & Keterangan \\
\hline Pre Test-Post Test & 0,985 & Normal \\
\hline
\end{tabular}

Berdasarkan tabel uji normalitas, hasil nilai Pre Test dan Post Test menggunakan aplikasi SPSS versi 21. Hasil Uji Normalitas data nilai, menunjukkan nilai Sig.(2-Tailed) berdistribusi normal. Itu dapat terlihat dari hasil Sig.(2-Tailed) bernilai 0,985 yang berarti bahwa hasil dari nilai tersebut normal.

\section{Uji Homogenitas}

Uji homogenitas dilakukan dengan mengunakan uji statistik descriptive SPSS, jika hasil analisis menunjukkan nilai $p>$ dari 0.05 , maka data tersebut homogen, akan tetapi jika hasil analisis data menunjukkan nilai $p<$ dari 0.05 , maka data tersebut tidak homogen. Hasil perhitungan dapat dilihat pada Tabel 2. dibawah ini.

Tabel 2. Uji Homogenitas Data Nilai Pre Test dan Post Test

\begin{tabular}{ccc}
\hline Hasil Tes & Nilai Sig (2-Tailed) & Keterangan \\
\hline Pre Test- Post Test & 0,442 & Homogen \\
\hline
\end{tabular}

Berdasarkan tabel Uji Homogenitas hasil nilai Pre Test dan Post Test menggunakan aplikasi SPSS Versi 21. Hasil Uji Homogenitas data nilai, meunjukkan nilai Sig.(2-Tailed) berdistribusi homogen atau sama. Itu dapat terlihat dari hasil Sig.(2-Tailed) bernilai 0,442 . Yang berarti bahwa hasil dari nilai tersebut norma atau homogen.

\section{Uji Paired Sample T-Test}

Pengolahan data dilakukan dengan menggunakan satistik program software kompter Stastistical Product and Service Solution (SPSS) 21. Pengujian hipotesis mengunakan uji paired sample t-test. Hasil uji hipotesis dapat dilihat pada Tabel 3. dibawah ini. 
Tabel 3. Paired Sample T-Test Data

\begin{tabular}{ccc}
\hline Hasil Tes & Nilai Sig (2-Tailed) & Keterangan \\
\hline Pre Test- Post Test & 0,000 & Berpengaruh \\
\hline
\end{tabular}

Berdasarkan tabel dari uji paired samples t-test hasil nilai pembelajaran play teach play menggunakan aplikasi SPSS Versi 21. Hasil uji paired sample t-test data, nilai menunjukkan sig.(2-Tailed). Itu dapat terlihat dari hasil sig.(2-Tailed) bernilai 0,000. Yang berarti bahwa hasil dari nilai tersebut terdapat pengaruh model pembelajaran play teach play terhadap kemampuan passing siswa pada permainan futsal di kelas VIII SMP Binaul Ummah.

\section{PEMBAHASAN}

Penerapan model pembelajaran Play Teach Play berdasarkan hasil penelitian menunjukan secara signifikan dapat meningkatkan kemampuan teknik dasar passing pada permainan futsal di SMP. Model pembelajaran play teach play dapat meningkatkan kemampuan passing pada permainan futsal karena secara karakteristik, model ini menitikberatkan kepada proses pembelajara dengan pendekatan bermain. Hasil penelitian terdahulu menunjukan bahwa pendekatan bermaian secara efektif dapat meningkatkan keterampilan teknik dasar pada olahraga permainan (Budi, Hidayat, \& Febriani, 2019; Eka \& Darmawan, 2014; Karisman, 2020).

Pembelajaran dengan pola permainan dapat meningkatkan ketermapilan passing futsal pada siswa SMP juga dikarenakan secara pertumbuhan dan perkembangan, siswa SMP memiliki motivasi yang tinggi dalam melakukan berbagai aktivitas permainan dan game dalam pembelajaran. Hasil penelitian terdahulu menunjukan bahwa kemampuan penguasaan teknik dasar dan bermain sepakbola pada siswa SMP menunjukan peningkatan yang signifikan dengan penerapan pendekatan bermain (Sujana, Muhtar, \& Nuryadi, 2014).

Model play teach play dengan pendekatan bermain membuat siswa terlibat secara aktif dalam pembelajaran sehingga dengan semakin aktif terlibat maka siswa dapat memiliki kesempatan untuk melakukan keterampilan dasar passing futsal selama pembelajaran, sehingga keterampilan passing dapat meningkat. Hasil penelitian terdahulu menunjukan bahwa keterlibatan siswa secara aktif dalam pembelajaran gerak 
Boby Agustan \& Ahmad Romi Hidayat | Play Teach Play: Pengaruhnya Terhadap Kemampuan Passing Futsal

efektif untuk meningkatan keterampilan motorik pada anak (Adi et al., 2019; Setiawan et al., 2020; Yuniko, 2018). Keterlibatan aktif siswa dalam pembelajaran tidak hanya disebabkan oleh banyaknya siswa melakukan keterampilan gerak, akan tetapi juga ditunjang oleh peran guru dalam memberikan arahan dan informasi selama pembelajaran.

Model play teach play dalam praktiknya dapat memfasilitasi hal tersebut, selain pendekatan bermain dan keterlibatan aktif siswa selama pembelajaran, model play teach play juga memiliki unsur teach. Proses teach atau mengajar, terlihat pada saat guru memberikan arahan dan informasi mengenai pembelajaran kepada siswa. Selain itu juga dapat dilihat pada saat guru melakukan evalusai pada saat pembelajaran, apabila ada siswa yang melakuan kesalahan gerak.

Peran guru menjadi sangat penting dalam keberhasilan pembelajaran dengan model play teach play. Hasil penelitian terdahulu menunjukan bahwa bimbingan yang diberikan guru dalam pemebelajaran keterampilan gerak membuat siswa lebih bersemangat dan mampu meningkatkan keterampilan dan keterlibatan pada proses pembelajaran (Basri, 2019; Sampurno \& Qohhar, 2020; Suherman, 2009).

Kombinasi yang ditunjukan antara pendekatan bermain dan peran guru dalam model play teach play menjadi bagian penting dalam kesuksesan siswa dalam meningkatkan keterampilan gerak teknik dasar futsal, khusunya di Sekolah Menengah Pertama (SMP). Penerapan model pembelajaran yang tepat dan didukung oleh keterampilan guru dalam mengelola kelas dapat membantu siswa untuk meingkatkan keterampilan gerak yang dimiliki.

\section{SIMPULAN}

Berdasarkan pada hasil dan pembahasa yang telah dikemukakan dapat disimpulkan bahwa penggunakan model pembelajaran play teach play dapat memberikan pengaruh yang positif pada siswa kelas VIII SMP Binaul Ummah karena dapat meningkatkan kemampuan passing futsal pada siswa. Moedel pembelajaran play teach play membuat siswa terlibat secara aktif dalam permainan sehingga kemampuan passing dapat meningkat dari sebelumnya. Saran yang dapat diberikan berdasarkan hasil penelitian yaitu guru penjas disarankan untuk menggunakan model play teach play dalam pembelajaran olahraga permainan, khusnya permainan futsal. Rekomendasi untuk 
penelitian selanjutnya dapat menerapkan metode pembelajaran yang berbeda atau model yang sama dengan teknik dasar atau teknik bermain olahraga permainan yang berbeda.

\section{REFERENSI}

Adi, H. S., Kristiyanto, A., \& Purnama, K. S. (2019). Peningkaasastan Keterampilan Teknik Dasar Futsal Melalui Penggunaan Media Video pada Mahasiswa Putra Penghobi Futsal. Prosiding Seminar Nasional IPTEK Olahragasasasasasa (SENALOG), 2(1), 21-24.

Aswadi, Amir, N., \& Karimuddin. (2015). Penelitian Tentang Perkembangan Cabang Olahraga Futsal Di Kota Banda Aceh Tahun 2007-2012. Jurnal IImiah Mahsiswa Pendidikan Jasmani, Kesehatan Dan Rekreasi, 1(1), 38-44.

Basri. (2019). Peningkatan Efektivitas Belajar Futsal dengan Modifikasi. Jurnal Pendidikan, 3(12), 1674-1679.

Budi, D. R., Hidayat, R., \& Febriani, A. R. (2019). The Application of Tactical Approaches in Learning Handballs. JUARA: Jurnal Olahraga. https://doi.org/10.33222/juara.v4i2.534

Budi, D. R., Kusuma, M. N. H., Syafei, M., \& Stephani, M. R. (2019). The Analysis of Fundamental Movement Skill in Primary School Student in Mountain Range. 11(Icsshpe 2018), 195-198. https://doi.org/10.2991/icsshpe-18.2019.56

Budi, D. R., \& Listiandi, A. D. (2021). Model Pembelajaran Dalam Pendidikan Jasmani. https://doi.org/https://doi.org/10.31219/osf.io/xzh3g

Danu Iksan , Sahputra Rachmat, W. (2013). Upaya Meningkatkan Teknik Dasar Passing Pada Futsal Dengan Metode Permainan Tradisional Kucing Bola Untuk Siswa Kelas Xi Ips Sma Muhammadiyah Nanga Pinoh. Jurnal Pendidikan Jasmani Kesehatan Dan Rekreasi, 1, 59-63.

Eka, G., \& Darmawan, B. (2014). Metode Pelatihan Taktis Passing Berpasangan Statis Dan Passing Sambil Bergerak Terhadap Keterampilan Teknik Dasar Passing Control Bola Futsal. E-Journal PKO, 1(2), 1-13.

Fahrizqi, E. B. (2018). Hubungan Panjang Tungkai, Power Tungkai Dan Koordinasi MataKaki Dengan Kemampuan Passing Pada Pemain Unit Kegiatan Mahasiswa Olahraga Futsal Perguruan Tinggi Teknorat. Journal of S.P.O.R.T, 2(1), 32-42.

Friskawati, G. F., Ilmawati, H., \& Suherman, A. (2017). Effect of Personalized System for Instructions (PSI) on Physical Fitness of Senior High School nursing's student. IOP Conf. Series: Materials Science and Engineering, 180(1). https://doi.org/10.1088/1757-899X/180/1/012262 
Boby Agustan \& Ahmad Romi Hidayat | Play Teach Play: Pengaruhnya Terhadap Kemampuan Passing Futsal

Gustiawati, R. (2016). Implementasi Model-Model Pembelajaran Penjas dalam Meningkatkan. Journal of Sport Science and Education (Jossae), 1(1).

Hadiana, O., Wahidi, R., \& Agustan, B. (2020). Efektivitas penerapan video feedback ( VFB ) terhadap motivasi belajar pada pembelajaran futsal. Jurnal SPORTIF: Jurnal Penelitian Pembelajaran, 6(1), 184-198.

Hadiana, O., Wahidi, R., Sartono, S., \& Agustan, B. (2020). The Impact of Video Feedback Toward Futsal Playing Skills. 21(Icsshpe 2019), 68-70. https://doi.org/10.2991/ahsr.k.200214.019

Jaenudin, J., Rusdiana, A., \& Kusmaedi, N. (2018). Pengembangan Media Latihan Passing Berbasis Arduino Uno dalam Cabang Olahraga Futsal. Jurnal Terapan IImu Keolahragaan, 3(1), 47. https://doi.org/10.17509/jtikor.v3i1.9925

Karisman, V. A. (2020). Implementasi Model Pembelajaran Terhadap Peningkatan Keterampilan Bermain Bola Voli. Physical Activity Journal, 2(1), 80. https://doi.org/10.20884/1.paju.2020.2.1.3096

Kharisma, Y., \& Mubarok, M. Z. (2020). Analisis Tingkat Daya Tahan Aerobik Pada Atlet Futsal Putri AFKAB Indramayu. Physical Activity Journal, 1(2), 125. https://doi.org/10.20884/1.paju.2020.1.2.2349

Narlan, A., Juniar, T., Millah, H., Jasmani, J. P., \& Keguruan, F. (2017). Pengembangan Instrumen Keterampilan Olahraga Futsal. Jurnal Siliwang, 3(2), 241-247.

Novriza, A. (2015). Hubungan Kecepatan Dengan Keterampilan Passing Bola Atlet Futsal Klub Airlangga Kabupaten Sijunjung. Acta Universitatis Agriculturae et Silviculturae Mendelianae Brunensis, 16(2), 39-55.

Nur, L., Malik, A. A., Juditya, S., Kastrena, E., Widyawan, D., Agustan, B., ... Yang, C. B. (2020). Comparison of two types of instruction in physical education. International Journal of Psychosocial Rehabilitation, 24(10), 1785-1793. https://doi.org/10.37200/IJPR/V24I10/PR300205

Nurhasan dan Hasanudin Chalil. (2007). Tes dan Pengukuran Keolahragaan. Bandung: FPOK Universitas Pendidikan Indonesia.

Permana, R., \& Istiadah, F. N. (2018). Play-Teach-Play Terhadap Peningkatan Kebugaran. Naturalistic: Jurnal Kajian Penelitan Pendidikan Dan Pembelajaran, 3(1).

Sampurno, H. W., \& Qohhar, W. (2020). Perbandingan Gaya Mengajar Terhadap Hasil Shooting Bola Basket. Physical Activity Journal, 1(2), 142. https://doi.org/10.20884/1.paju.2020.1.2.2493

Setiawan, A., Yudiana, Y., Ugelta, S., Oktriani, S., Budi, D. R., \& Listiandi, A. D. (2020). Hasil Belajar Pendidikan Jasmani dan Olahraga Siswa Sekolah Dasar: Pengaruh Keterampilan Motorik (Tinggi) dan Model Pembelajaran (Kooperatif). TEGAR: Journal 
of Teaching Physical Education in Elementary School.
https://doi.org/10.17509/tegar.v3i2.24513

Sugiyono, P. D. (2016). metode penelitian kuantitatif, kualitatif,dan R\&D. In Alfabeta, CV. Bandung: Alfabeta.

Suherman, A. (2009). Revitalisasi Pengajaran dalam Pendidikan Jasmani. Bandung: CV. Bintang Warli Artika.

Sujana, R., Muhtar, T., \& Nuryadi, N. (2014). Pengaruh Pendekatan Pembelajaran Dan Motor Educability Terhadap Hasil Belajar Teknik Dasar Dan Keterampilan Bermain Sepakbola. Edusentris, 1(3), 260. https://doi.org/10.17509/edusentris.v1i3.150

Ulfah, W. A. (2019). Pengaruh Model Pembelajaran Play Teach Play Terhadap Hasil Belajar Pasing Bawah Bola Voli Siswa Kelas Viii Smp Negeri 2 Sungailiat. Jurnal Pendidikan Glasser, 3(1), 134. https://doi.org/10.32529/glasser.v3i1.158

Yuniko, G. (2018). Hubungan Kemampuan Motorik dengan Hasil Belajar Penjas Siswa Sekolah Dasar Negeri 194 Kabupaten Tebo. 1(1), 61-66. 